\title{
Kolb's learning style analysis in solving HOTS questions for prospective physics teacher students
}

\author{
Nengah Nitriani ${ }^{a}$, Darsikin Darsikin ${ }^{b}$, Sahrul Saehana ${ }^{c *}$ \\ Universitas Tadulako. Jl. Soekarno Hatta Km. 9 Palu 94118, Indonesia \\ a nengah.nitriani@gmail.com; ${ }^{b}$ darsikinfis@gmail.com; c sahrulsaehana@gmail.com \\ * Corresponding Author.
}

Received: 25 August 2021; Revised: 17 October 2021; Accepted: 11 November 2021

\begin{abstract}
This study aims to analyze Kolb's Learning Style (KLS) in solving HOTS questions for prospective physics teacher students. This research is a descriptive study using a qualitative approach. The subjects of this research are second-semester students who have joined the Basic Physics course for Archimedes' Principle, amounting to 46 people. The instrument used was a Kolb's Learning Style (KLS) questionnaire, which consisted of 40 statement items, eight essay questions about HOTS, and interview guidelines. Based on the results of the study, it showed that from the maximum percentage $(100 \%)$ in each Kolb's Learning Style (KLS) obtained the combination of diverger and assimilator learning styles as the highest average percentage (65.63\%) in solving HOTS questions correctly compared to the other learning styles. It is followed by the accommodator (56.25\%), the combination of assimilator and converger (54.17\%), diverger (53.41\%), assimilator $(49.22 \%)$, and converger (48.61\%). There are differences in Kolb's Learning Style (KLS) in solving HOTS questions for prospective physics teacher students where students still experience errors in answering questions. The forms of incorrect answers given by students include: (1) Objects with a smaller surface area must be a sink, (2) Heavy objects must be the sink, (3) The amount of water affects the state of floating and sinking, (4) Hollow objects always float, and (5) Objects made of something hard must be sink. Based on the results of this study, it can be concluded that prospective physics teacher students' ability to solve HOTS questions must be trained by adjusting their learning styles.

Keywords: Kolb's Learning Style; HOTS; Archimedes' principle
\end{abstract}

How to Cite: Nitriani, N., \& Saehana, S. (2022). Kolb's learning style analysis in solving HOTS questions for prospective physics teacher students. Momentum: Physics Education Journal, 6(1), 59-72. https://doi.org/10.21067/mpej.v6i1.5593

\section{Introduction}

In physics learning, each student has a different understanding, both in terms of performance level and learning style. This difference in learning styles shows the easiest way for students to absorb information during learning and how to organize and process that information into a success in the learning process (Viloria et al., 2019). This is reinforced by a statement stating that knowing a person's learning style is an important indicator in the teaching and learning process to achieve maximum results. One's achievement is determined by how one can receive and manage information optimally, such as learning styles and tendencies during the teaching and learning process. Therefore, in learning activities, students really need to be assisted and directed to recognize learning styles that suit themselves so that learning objectives can be achieved effectively (Ajideh et al., 2018).

Diverger style is a combination of elements of Concrete Experience (Feeling) and Reflective Observation (Watching). Individuals with this style are able to see concrete situations from various perspectives. Some learn with assimilator style, which is a combination of Abstract Conceptualization 
(Thinking) and Reflective Observation (Watching). This individual is skilled in processing a lot of information and placing it in a definite and logical form. Then there are students who study with a converger learning style, a combination of Abstract Conceptualization (Thinking) and Active Experimentation (Do). These individuals are best at finding practical uses for ideas and theories. In addition, some students learn with the accommodator learning style, which is a combination of Concrete Experience (Feeling) and Active Experimentation (Do) (Vasil'ev \& Gorelikov, 1998).

If students understand their own learning style, it will be easier for them to learn something and increase motivation to display their best abilities. Individual abilities can be assessed from their ability to think independently and are able to use HOTS (Higher Order Thinking Skills) as independent professionals (Jarvis \& Baloyi, 2020). However, in reality, students still experience weak thinking skills. At the same time, one of the skills that must be possessed in the 21st Century is HOTS, which includes the ability to think critically, creatively, and solve problems (Tyas et al., 2019).

In this study, researchers chose the Physics Education Study Program at Tadulako University to analyze that the achievements of prospective physics teacher students reflected HOTS (Higher Order Thinking Skills) and the scores obtained by students were not only based on low-level thinking skills or LOTS (Lower Order Thinking Skills) which is only oriented to the achievement of values. Therefore, by conducting research on solving HOTS (Higher Order Thinking Skills) questions on prospective physics teacher students, it is hoped that it can provide new knowledge so that students' problem solving is not only oriented to memorization skills but also to cognitive processes (way of thinking) that can encourage students to think to a higher level (Retnawati et al., 2018). This is supported by the results of research (Kwangmuang et al., 2021), which states that HOTS students must be trained. One of the efforts to train students' thinking skills, especially higher-order thinking skills, is to train themselves to solve HOTS questions.

Based on the above explanation, the author has analyzed Kolb's Learning Style (KLS) in solving HOTS questions for prospective physics teacher students, especially students who have joined the Basic Physics course for Archimedes' Law. The Archimedes law material was chosen in this study because the application of the law is easily found in everyday life. It is hoped that this research will analyze Kolb's Learning Style (KLS) in solving HOTS questions for prospective physics teacher students, especially on Archimedes' Law material and add reference material for further research.

Based on previous research, learning styles have a significant effect on problem-solving abilities and significantly affect student achievement (Istiningtiyas, 2021). In addition, higher-order thinking skills in students are closely related to the learning styles of each student (Pantas \& Hasruddin, 2020). Learning styles also affect students' critical thinking skills, and each has a different level (Lwande et al., 2021). People who have a learning style can develop more skills and achieve better results (Gamboa Mora et al., 2021). Kinesthetic learning styles can also affect students' mathematical creative thinking skills (Yuniarti et al., 2021). Therefore, this research is important in order to improve students' HOTS in learning physics by recognizing their respective learning styles. The results of this study also seek to provide practical-empirical benefits in the form of students' knowledge and understanding of each individual's learning styles, which in turn will be taken into consideration for teaching staff to minimize student ineffectiveness in the learning process.

Although many have revealed David Kolb's learning style, so far, no one has analyzed how David Kolb's learning style is in solving HOTS questions. So the purpose of this study was to analyze Kolb's Learning Style (KLS) in solving the HOTS Questions for Prospective Physics Teacher Students, especially on the subject of Arhimedes' Law.

\section{Methods}

This research is a qualitative or naturalistic descriptive study because it is carried out on natural object conditions that aim to analyze students' HOTS abilities based on learning styles in the form of descriptions (Kholid et al., 2020). The natural object in question is the object as it is, not manipulated by the researcher so that the conditions when the researcher enters the object, after being in the object and after leaving the object, are relatively unchanged. The subjects in this study 
were active 46 students of Physics Education semester II FKIP Tadulako University who had attended Basic Physics courses and had passed Archimedes' Law material. Each of them had David Kolb learning style. This study uses a purposive sampling technique, which is selecting informants who have attended the Basic Physics course on Archimedes' Law and students who have David Kolb's learning style. Before selecting informants, the researcher gave Kolb's Learning Style (KLS) questionnaires to students and analyzed the questionnaire to determine the learning styles of prospective physics teacher students and then analyzed their ability to solve HOTS questions.

Broadly speaking, the stages of this research are divided into three parts: preparing a research design, choosing a location, managing permits, exploring and assessing the situation, selecting and utilizing informants, and preparing research instruments. Next is the implementation stage, which is to provide students with an adapted David Kolb learning style questionnaire and HOTS question sheets and conduct interviews to gather information about the problems that occur when answering HOTS questions. The last stage is processing and analyzing data and writing research reports.

The instruments used in this study are KLS questionnaires, HOTS questions, and interview guidelines that material expert validators have validated.

\section{Questionnaire of Kolb's Learning Style}

The questionnaire consists of 40 statements filled out by students by giving a score of 1-5 on the statement where the score given is the level of confidence. The greater the score is given, the greater the level of confidence or the more in accordance with the students themselves. The statement can be seen in Table 1.

Table 1. Number of Respondents in Each Type of KLS

No. Statement

1. I have strong beliefs about Archimedes' Law material which I find useful.

2. I solve the problem of learning Archimedes' Law material given by the lecturer in sequence.

3. I am interested in studying Archimedes' Law by doing the given task.

4. When studying Archimedes' Law material, I like to involve my feelings.

5. I avoid the less useful Archimedes' Law material.

6. I asked the teacher for the difficult Archimedes Law material.

7. I can't easily socialize with friends.

8. I know my friend's mistake during the discussion.

9. I am interested in exploring Archimedes' Law materials that support the phenomena I encounter in the environment.

10. In discussions, I never side with any of my friends' opinions.

11. I paid close attention to the Archimedes Law practicum in the Basic Physics Practicum Guide module by UPT. Labdas Tadulako University.

12. I'm not easy to draw conclusions.

13. I wrote a complete practicum report.

14. I read the manual before doing the Basic Physics practicum, especially the Archimedes Law material.

15. In discussing, I prefer to listen to other people's opinions than to have opinions.

16. I solve Archimedes' Law problems from various points of view.

17. I prefer to have multiple sources of information (such as books, journals and the internet) to search for Archimedes' Law material.

18. I prefer to consider something before working on it.

19. I like listening more than talking.

20. I'm curious about what my friend is thinking.

21. In discussing, I like to get straight to the core of the matter.

22. When I listen to a friend's idea, I like to immediately implement it.

23. I like judging friends' ideas.

24. When I studied Archimedes' Law, I was a rational person.

25. I like to create flowcharts for writing practical methods or taking notes.

26. I like to be realistic when the discussion or not to beat around the bush.

27. I have a practical idea in solving the problem.

28. I write a practical report briefly and clearly. 
No. Statement

29. I don't like it when friends make deviant statements during discussions.

30. Before the Basic Physics practicum, I like to prepare practical tools and materials.

31. I like working on Archimedes' Law assignments given by the lecturer.

32. I like to answer questions from lecturers.

33. I like to act without thinking about the consequences.

34. I like new challenges.

35. I prefer to respond spontaneously.

36. In doing practicum, I like to try something new.

37. When a friend is in trouble, I will rush to help.

38. I like to talk a lot.

39. I like to invite friends to study together.

40. In discussing, I am active in speaking.

\section{HOTS Question}

The HOTS questions consist of eight description questions in the analyze indicator. These questions have been validated by material expert validators to be used in analyzing students' ability to solve HOTS questions.

\section{Interview guidelines}

Interview guidelines refer to questions related to problems that occur to students in solving HOTS questions. The interviews were not rigid and only focused on interview guidelines but developed and flowed according to the conditions in the field.

Based on the Miles and Huberman model, the data analysis process in this study consisted of three steps, namely data reduction, data presentation and conclusion drawing. After data collection, the activity carried out was to make a transcript of all the recordings. The results of the transcript were reduced, things that were not related to the research objectives were removed from the transcript. The reduced data were analyzed for further conclusions drawn. Data analysis in this study uses an average description that explains students' ability to solve HOTS questions based on their learning style. Descriptions are carried out for each HOTS question.

\section{Result and Discussion}

Result

The results of the analysis of Kolb's Learning Style (KLS) or David Kolb's learning style owned by each respondent, in this case, are students who are prospective physics teachers. Kolb's Learning Style (KLS) owned by each respondent can be seen in Table 2 .

Table 2. Number of Respondents in Each Type of KLS

\begin{tabular}{lc}
\hline \multicolumn{1}{c}{ Types of KLS } & Number of Respondents (Person) \\
\hline Diverger & 11 \\
Assimilator & 16 \\
Converger & 9 \\
Accommodator & 3 \\
Combination of Diverger\& Assimilator & 4 \\
Combination of Assimilator \& Converger & 3 \\
\hline Total Respondents & 46 \\
\hline
\end{tabular}

In Table 2, it can be seen that 46 total respondents have different learning styles. In the research that has been done, there are six learning styles owned by the respondents, including diverger, assimilator, converger, accommodator, a combination of diverger \& assimilator, and combination of assimilator \& converger. 
The respondent's learning style is related to prospective physics teacher students' ability to solve HOTS questions on Archimedes' Law material consisting of 8 HOTS type description questions in the C4 domain, analyzing, with the indicators as shown in Table 3.

Table 3. Indicators of Archimedes' Law Material Questions Analyzing Indicators of C4 Analyzing Archimedes' Law Material Questions

\begin{tabular}{lc}
\hline \multicolumn{1}{c}{ Question Indicator } & Question \\
& No. \\
\hline Relating the influence of the surface area of objects on the events of floating on, floating in, sinking & $1 \& 2$ \\
Relating the effect of the object density on the concept of floating on, floating in, sinking & $3 \& 7$ \\
Relating the effect of large amounts of water on buoyancy & 4 \\
Distinguishing the position of objects in fluids of different densities. & 5 \\
Relating the effect of an object's volume on buoyancy. & 6 \\
Relating the effect of the volume of fluid displaced on the magnitude of the buoyant force. & 8 \\
\hline
\end{tabular}

The results of the data analysis on the HOTS material of Archimedes' Law that have been done correctly by the respondents can be seen in Table 4 .

Table 4. Average Percentage of Respondents Answering Correctly on HOTS Questions on Archimedes' Law Materials

\begin{tabular}{cc}
\hline Question No. & The average percentage of HOTS in Respondents (\%) \\
\hline 1 & 73.90 \\
2 & 71.74 \\
3 & 58.69 \\
4 & 60.87 \\
5 & 65.22 \\
6 & 19.57 \\
7 & 34.78 \\
8 & 41.30 \\
\hline
\end{tabular}

Based on Table 2 and Table 4, the relationship between Kolb's Learning Style (KLS) in solving HOTS questions for prospective physics teacher students can be analysed as seen in Table 5.

Table 5. Kolb's Learning Style in Solving HOTS Problems with Archimedes' Law for Prospective Physics Teacher Students

\begin{tabular}{lcc}
\hline \multicolumn{1}{c}{ KLS Types of Respondents } & $\begin{array}{c}\text { Number of } \\
\text { Respondents }\end{array}$ & $\begin{array}{c}\text { Average Ability of Respondents in Solving HOTS } \\
\text { Questions Correctly (\%) }\end{array}$ \\
\hline Diverger & 11 & 53.41 \\
Assimilator & 16 & 49.22 \\
Converger & 9 & 48.61 \\
Accomodator & 3 & 56.25 \\
Combination of Diverger \& Assimilator & 4 & 65.63 \\
Combination of Assimilator \& Converger & 3 & 54.17 \\
\hline
\end{tabular}

Table 5 shows that the percentage of Kolb's Learning Style in Solving HOTS Problems on Archimedes' Law material for prospective physics teacher students varies based on the type of learning style owned by the respondents. In the following, 8 cases of Archimedes' Law and students' perceptions based on HOTS abilities and their relation to learning styles are presented.

\section{Question 1}

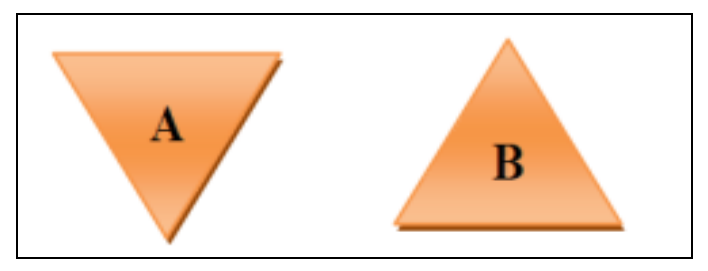

Figure 1. Two identical objects 
Objects $A$ and $B$ are identical and made of the same material; if object $B$ floats on a fluid, what about object $A$ ? The perception of respondents' answers to question 1 is presented in Figure 2 .

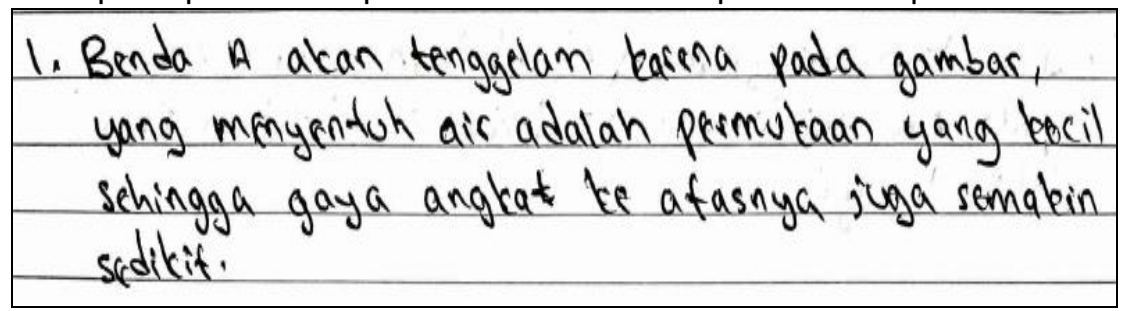

Figure 2. Argumentation of R33 (Assimilator \& Converger) for Question 1

Based on the interviews, respondents said that objects with a small surface area will float in and even sink when placed in a fluid. The reason is that respondents are guided by the general equation of pressure, namely force per unit area. Therefore, the smaller the surface area of an object, the greater the pressure experienced.

\section{Question 2}

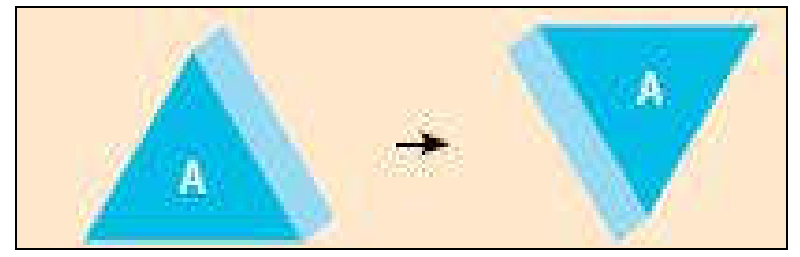

Figure 3. Changing Position of Objects

When block $A$ is placed in the water to the left, block $A$ floats on. Meanwhile, if we turn the ends as in the picture on the right, what is the position of block $A$ if it is put back in the water? The perception of respondents' answers to question 2 is presented in Figure 4.

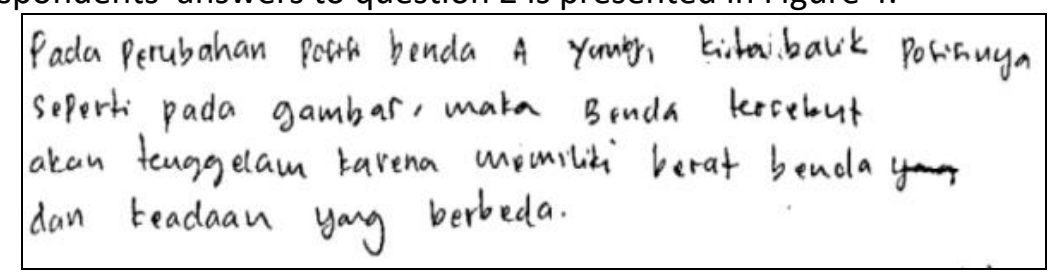

Figure 4. Argumentation of R36 (Diverger) for Question 2

Based on the interviews, respondents said that objects with different conditions and small surface areas (pointed surfaces) have greater pressure, causing objects to sink. The reason is that the heavier the object, the greater the pressure to sink.

\section{Question 3}

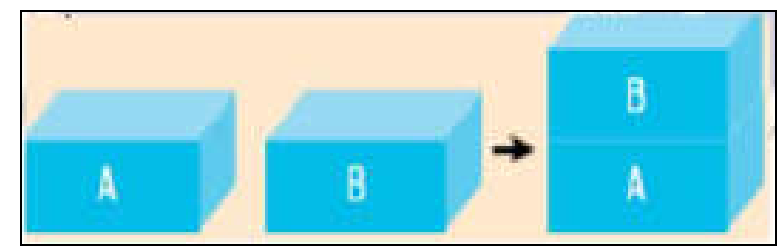

Figure 5. Blocks $A$ and $B$ are stacked

Block $A$ and Block $B$ both float in water. Suppose we attach the two sides and we put them in the water together; what is the condition of the block after it is put in the water? The perception of respondents' answers to question 3 is presented in Figure 6. 


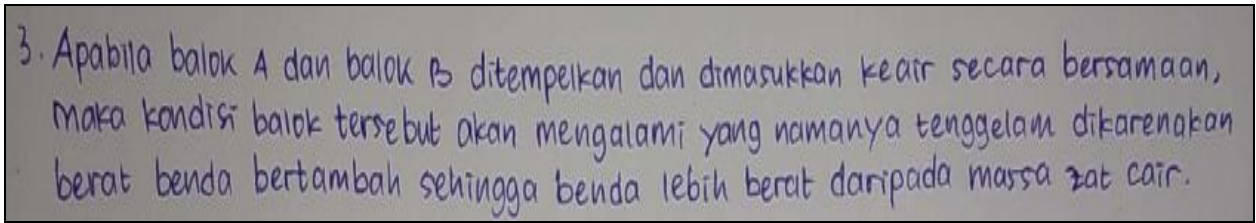

Figure 6. Argumentation of R42 (Assimilator) for Question 3

Based on the results of the interview, respondents said that when object $A$ and object $B$ were stacked, the mass of the object increased. The increase in mass causes the two objects to sink. Respondents also said that when object $A$ and object $B$ are put together, the weight of the object will increase, so the respondent assumes that heavy objects will sink, light objects will float on.

\section{Question 4}

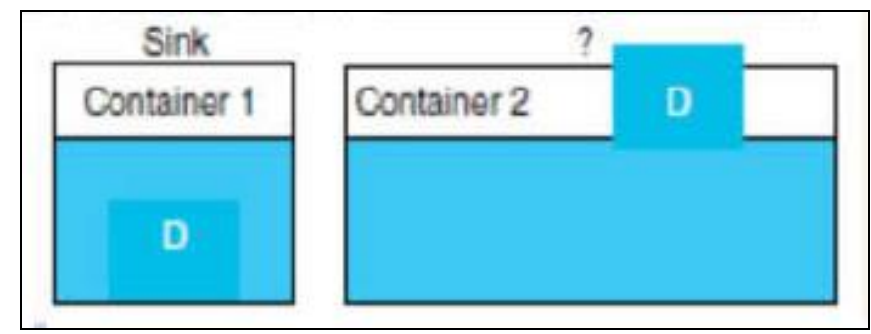

Figure 7. Container 2 Has More Water

Block $D$ is sinked in the water in container 1 . When block $D$ is placed in a container that has more water (container 2), what is the condition of block $D$ ? The perception of respondents' answers to question 4 is presented in Figure 8.

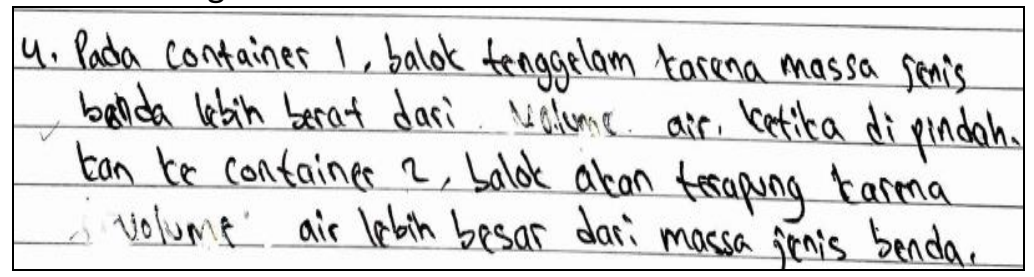

Figure 8. The argument of R33 (Combination of Assimilator and Converger) for Question 4

Based on the results of interviews, respondents said that a large amount of water makes an object float on so that at the time of the interview, the average respondent explained that object $D$ would float in container two due to the amount of water held by the container 2 . Respondents really did not understand the magnitudes, which affects the buoyancy of an object.

\section{Question 5}

An identical ship is in the lake and the sea. If the viewing distance is the same, which one looks bigger? The perception of respondents' answers to question 5 is presented in Figure 9.

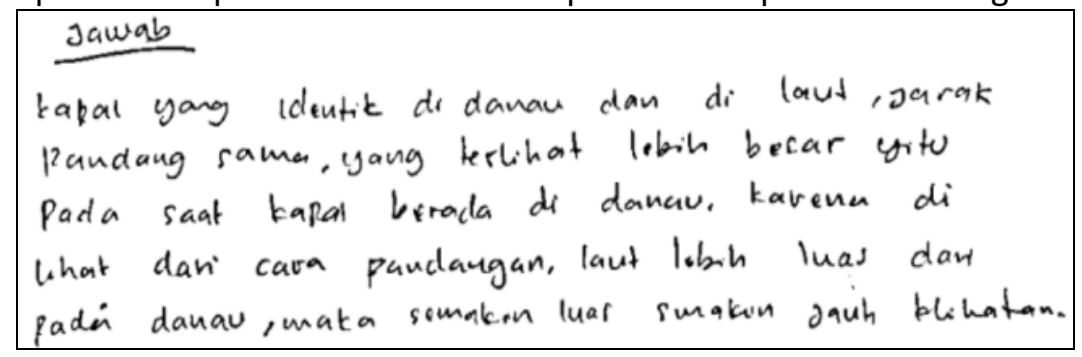

Figure 9. The argument of R36 (Diverger) or Question 5

The results of interviews conducted showed that respondents were still wrong in explaining the cause of the buoyancy of an object. In question 5, students' perceptions show that the ship looks 
bigger when it is on the lake because the lake is narrower than the sea, and seawater has more water than the lake, so that is what causes the ship to look bigger when in the lake.

\section{Question 6}

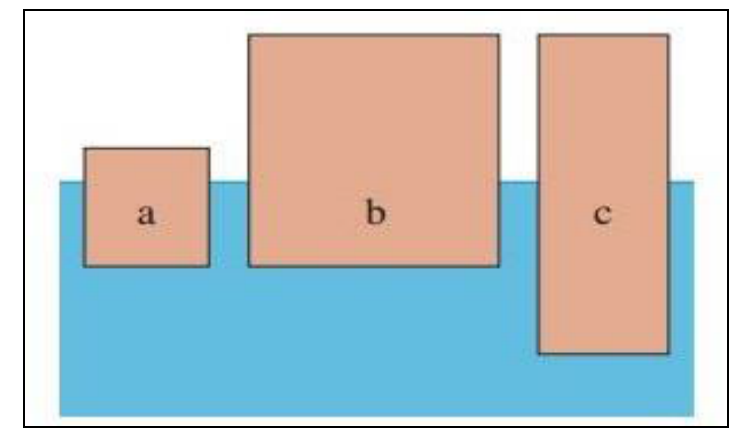

Figure 10. Blocks inserted in Substance

Three objects of different densities are placed in the water. All three float on the surface of the water, as shown in the image below. Order the thickness of the objects from least to greatest. The perception of respondents' answers in case 6 is presented in Figure 11.

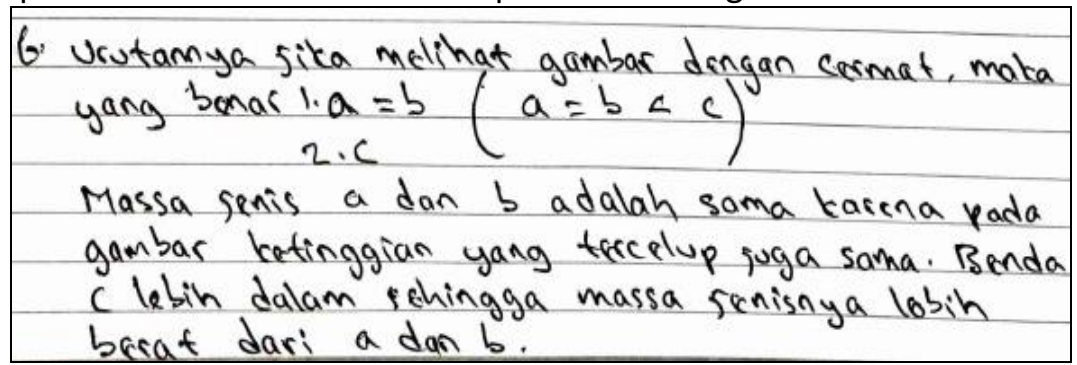

Figure 11. The argument of R33 (Combination of Assimilator and Converger) for Question 6

Based on the results of the interview, the respondents assumed that if the objects immersed in the liquid were at the same height, then apart from having the same volume, the density was also the same. Whereas the actual concept, if we look at the shape of objects between objects a and $b$, it clearly shows a significant difference. Object $a$ is smaller than object $b$, but when it is immersed in a liquid, the height of the object that is submerged is the same. This shows that the density of object $b$ is less than that of object a. While object $c$ that is immersed more in the liquid has a greater density. In this case, the student's perception is considered correct.

\section{Question 7}

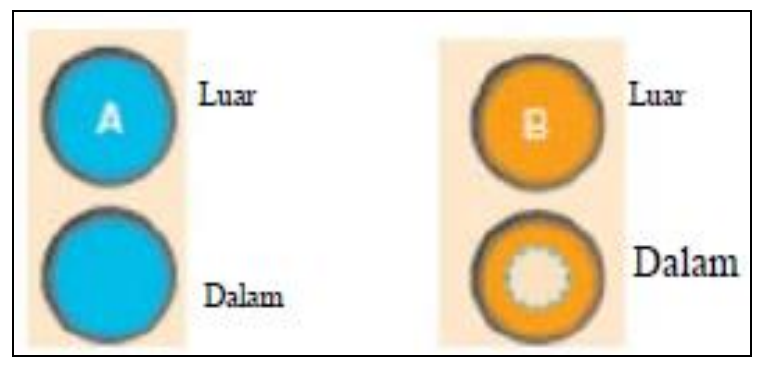

Figure 12. Different Shapes of Objects A and B

Two balls, ball $A$ and ball $B$ are made of different materials, but they have the same mass and volume. Ball $A$ is solid, and ball $B$ has a cavity in it. If ball $A$ is placed in water, it will sink; what will happen to ball $B$ ? The perception of respondents' answers to question 7 is presented in Figure 13. 


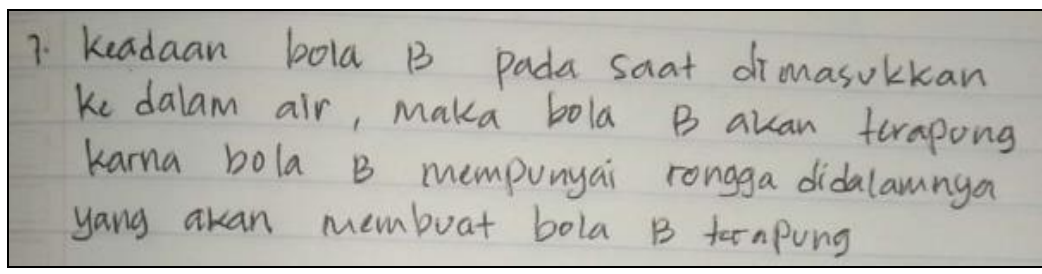

Figure 13. The argument of R41 (Diverger) for Question 7

Based on the interview results, respondents said that hollow objects will always float on because ball $B$ has a cavity on the inside, causing air to enter ball $B$ and cause ball $B$ to float in. There are even respondents who say ball B will float. This shows that students' understanding of concepts is still relatively low.

\section{Question 8}

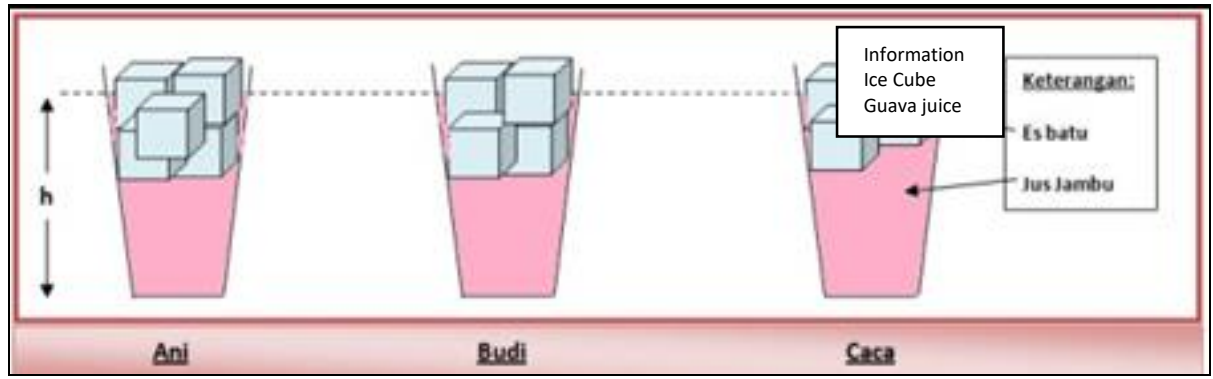

Figure 14. The Height of Guava Juice in the Glasses are the Same

If the height of the guava juice after adding the ice cubes belonging to Ani, Budi, and Caca in the glass is the same, what happens when the ice melts? The perception of respondents' answers to question 8 is presented in Figure 15.

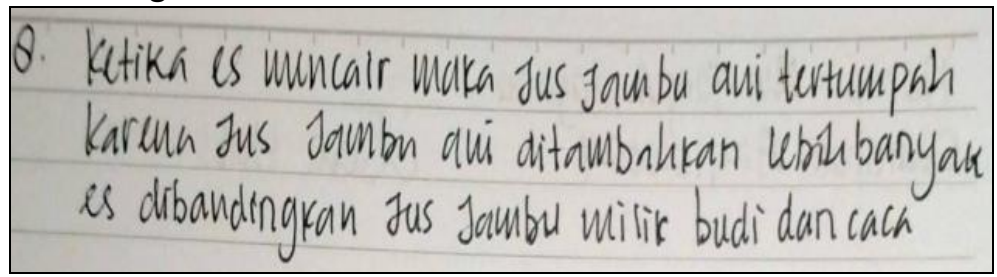

Figure 15. The argument of R12 (Assimilator) for Question 8

Based on the results of the interviews, respondents assumed that the volume of liquid transferred was influenced by the amount of ice added to the guava juice. Because the number of ice cubes placed in A's container is more, according to participants, the guava juice in Ani's container spills the most. In this case, participants do not understand the factors that affect buoyancy. Participants were also less thorough and did not interpret the statement that the final height of guava juice after being given ice cubes was the same as a keyword.

\section{Discussion}

If students understand their own learning style, it will be easier for them to learn something and improve their HOTS because solving HOTS questions is one of the skills that students in the 21st Century must possess. Previous research has stated that learning styles significantly affect problemsolving abilities (Istiningtiyas, 2021). This is because an appropriate learning style will improve learning, and students tend to have better performance or higher levels of satisfaction (Dermawan et al., 2021). Therefore, it is important to conduct this research to determine the students' HOTS ability on Archimedes' Law material by recognizing their respective learning styles.

Based on the study results, it can be seen that there are differences in the learning styles of each respondent. In the results of data analysis that has been carried out, there are six types of learning styles owned by respondents, including Diverger (11 respondents), Assimilator (16 respondents), 
Converger (9 respondents), Accommodator (3 respondents), a combination of Diverger \& Assimilator (4 respondents) and a combination of Assimilator \& Converger (3 respondents). In the data that has been analyzed it is known that Kolb's Learning Style (KLS) in solving HOTS questions correctly for prospective physics teacher students shows that from the maximum percentage $(100 \%)$ in each Kolb's Learning Style (KLS) obtained, a combination of divergent learning styles and assimilator $(65.63 \%)$ has the highest average percentage compared to other learning styles, followed by accommodator $(56.25 \%)$, combination assimilator and converger $(54.17 \%)$, diverger $(53.41 \%)$, assimilator (49.22\%), and converger ( $48.61 \%)$. There is a difference in the distribution of the ability to solve HOTS questions based on the learning style of each student. The results in this study are in accordance with previous research, which proves that each different learning style has different literacy abilities, according to David Kolb in the learning process (Zhong \& Wang, 2021).

Based on the data obtained, the combination of diverger and assimilator learning styles has the highest average percentage (65.63\%) compared to other learning styles in solving HOTS questions because the diverger learning style students have several criteria, including students like to solve problems learning the Archimedes Law material which given by lecturers and students interested in studying Archimedes' Law material by doing the assigned tasks. As well as on the assimilator learning style, students also have one of the criteria that is relevant to the research being carried out. Namely, students like to solve Archimedes' Law questions from various points of view. The combination of diverger and assimilator learning styles makes students both have the characteristics of liking to solve problems so that this combination learning style has the highest percentage of solving HOTS questions. This is because students with the highest representational abilities tend to have an assimilator learning style (Hajaro et al., 2021). Diverger learning styles are also more dominant in problem-solving skills (McKenna et al., 2018). Based on previous research, it is proven that learning styles influence students' abilities in solving HOTS questions so that the better the student's learning style, the better the ability to solve HOTS questions.

The accommodator learning style has the second-highest average percentage (56.25\%) in solving HOTS questions because the student accommodator learning style has several criteria, including students who are interested in studying Archimedes' Law material by working on problemsolving problems given by the lecturer, both in the form of content and description, because students with this learning style are very fond of solving new things. The combination of assimilator \& converger learning styles has the fourth-highest average percentage $(54.17 \%)$ in solving HOTS questions. Based on the statement in the questionnaire, students are less fond of solving Archimedes' Law questions (R17 \& R28).

The diverger learning style has the fourth-highest average percentage $(53.41 \%)$ in solving HOTS questions because the reflective observation (watching) pole in the diverger student makes the student approach each situation by observing not acting so that they are less fond of solving questions. The assimilator learning style has the fifth-highest average percentage $(49.22 \%)$ in solving HOTS questions because students with assimilator learning styles in this study are more interested in abstract concepts than applications and solving problems and students also like to integrate their observations. Into a theory.

The converger learning style has the lowest average percentage $(48.61 \%)$ in solving HOTS questions. Based on the statement in the questionnaire, students do not like to work on Archimedes' Law questions given by the teacher, but the active experimentation (doing) pole that exists in students with a converger learning style tends to make these students active during the learning process and practicum on Archimedes' Law material.

The results of this study also showed that there were errors in the answers given by students, including (1) Objects with a smaller surface area must sink; (2) Heavy objects must sink; (3) The amount of water affects the state of floating on, floating in, and sinking; (4) Hollow objects always float, and (5) Objects made of something hard must sink. The emergence of this conceptual error shows that the ability of prospective physics teachers is still low in solving HOTS cognitive questions (Ain, 2021). Previous research found that learning style significantly influences students' conceptual errors caused by the way of thinking used, namely the intuitive mindset when responding to and 
solving problems encountered (Abosalem, 2013; Sen \& Yilmaz, 2012). The mindset of students can be influenced by the learning process received during teaching and learning activities (Falloon, 2019).

The cause of incorrect answers in solving HOTS questions on Archimedes' Law material that occurred to prospective physics teacher students was also caused by the student's learning style. The cause of conceptual errors in the divergent learning style is online learning during a time-limited pandemic. This makes diverger students lose money because of the lack of optimal understanding of the material provided, resulting in less effective learning. Such conditions make students tend to have incomplete understandings that allow students to misconstrue as a result of the online learning methods applied (Binali et al., 2021). Students who have a divergent learning style will learn better when given facts and procedures, but based on interviews conducted during learning, most of what is discussed in the Archimedes Law material only focuses on abstract concepts, formulations, and theories. This difficulty is experienced by students who have divergent learning styles in understanding it. This lack of skills can potentially cause students to experience errors when solving HOTS questions.

The causes of conceptual errors in the assimilator learning style, the lack of explanations of case examples in everyday life and their relation to the concept of Archimedes' Law. Students need to be trained to complete examples of Archimedes' Law during online lectures, in this case, the HOTS level case example. Giving sample questions at the HOTS level on a regular basis can improve thinking skills so that they can be trained to develop their cognitive abilities so that later they can compete (Arafah et al., 2021).

The cause of the concept error in the converger learning style is that the practicum activities that are carried out are not optimal. Practicum conducted in online lectures is limited by time so that students do not fully understand the concepts being studied. This problem resulted in students' errors when solving HOTS questions.

The cause of the concept error in the accommodator learning style is the teaching strategy applied by the lecturer is not in accordance with the student's learning style. Lecturers should conduct learning by providing real facts and close to student life in accordance with the material being taught so that students can have a comprehensive understanding of Archimedes' Law.

The connection between research conducted during online learning during the Covid-19 pandemic is that it can positively and negatively impact students' cognitive abilities, especially in this case, namely the ability to solve HOTS questions on Archimedes' Law material by prospective physics teacher students. The positive impact lies in the learning styles of assimilator (first highest number of respondents) and divergent (second-highest number of respondents). Both learning styles are influenced by observation (watch). In online learning, even students with assimilator and diverger learning styles can absorb and process information because students are more interested in abstract concepts than applications. Students in this learning style are also diligent in summarizing learning and tend to work alone so that with these characteristics, the assimilator and diverger learning styles can learn well in online learning during a pandemic like now. This is in line with previous research which says that it is important for teachers to understand students' learning styles as an orientation in determining the right learning media during online learning. The research results showed that the most preferred visual learning style (observation/watch) was the most appropriate when learning online (Patricia Aguilera-Hermida, 2020).

The negative impact lies in the converger and accommodator learning styles which are both influenced by the action element (do). Students with this learning style are less than optimal in online learning because students with this type have criteria who like hands-on practicums in order to understand a concept being taught, while online learning practicum is only done using a simulated PhET application or Virtual Laboratory, so the process is This causes students with this learning style to not be able to learn optimally and results in a lack of student understanding of the concept of Archimedes' Law and has an impact on the process of solving HOTS questions for students who still experience many errors.

The difference between the research conducted with previous research is (i) previous research is only limited to examining the learning styles of students without further looking at the relationship 
between learning styles and students' abilities such as the HOTS ability, (ii) there are respondents who have multiple learning styles such as a combination of diverger and assimilator (4 students) as well as a combination of assimilator and converger ( 3 students) which previous researchers have never obtained results. This is in line with what is described by Kolb, who argues that there is no individual whose learning style is absolutely dominated by just one of these poles. Usually, what happens is a combination of two or more poles and forms a trend (Jalinus et al., 2020).

Based on the interview results, the average respondents who have multiple learning styles (R9, $R 17, R 28, R 30, R 33, R 34$, and R35) say that it is very good if learning both types of learning styles are combined with absorbing, organizing, process and be able to solve more problems. Quickly and easily, and by combining these learning styles, the impact can improve understanding and learning outcomes. Respondents combine learning styles or study habits to understand what is being learned more quickly.

This research is also expected to be useful for related parties in order to provide understanding to students regarding the forms of learning styles that students dominate so that they can be used as methods in learning in order to get good learning outcomes and can improve students' higher-order thinking skills or HOTS Ponyo.

\section{Conclusion}

Based on the results of the analysis and discussion, this research can be concluded, from the maximum percentage (100\%) in each Kolb's Learning Style (KLS), it is obtained that the combination of diverger and assimilator learning styles (65.63\%). It has the highest average percentage in completing HOTS questions correctly compared to other learning styles because, in the divergent learning style, students have criteria including students like solving problems learning Archimedes' Law material given by lecturers and students interested in studying Archimedes' Law material by doing the assigned tasks. As well as on the assimilator learning style, students also have one of the criteria relevant to the research conducted. Namely, students like to solve problems, then followed by accommodators (56.25\%), a combination of assimilator and converger (54.17\%), diverger (53.41\%), assimilator (49.22). \%), and converger (48.61\%). There are differences in Kolb's Learning Style (KLS) in solving HOTS questions for prospective physics teacher students. Students still experience errors in answering questions. The forms of incorrect answers given by students include (1) Objects with a smaller surface area must sink; (2) Heavy objects must sink; (3) The amount of water affects the state of floating on, floating in, and sinking; (4) Hollow objects always float on; and (5) Objects made of something hard must sink.

\section{References}

Abosalem, Y. M. (2013). The relationship between the learning styles of students in grades five and six and their held misconceptions about dividing fractions based on Kolb's model. The British University in Dubai (BUiD). https://bspace.buid.ac.ae/handle/1234/511

Ain, N. (2021). Prospective physics teacher's ability in developing HOTS questions: CRI analysis. Momentum: Physics Education Journal, 5(1), 85-93. https://doi.org/10.21067/mpej.v5i2.5566

Ajideh, P., Zohrabi, M., \& Pouralvar, K. (2018). Investigating the relationship between learning styles and ESP reading strategies in academic setting. International Journal of Applied Linguistics and English Literature, 7(3), 156. https://doi.org/10.7575/aiac.ijalel.v.7n.3p.156

Arafah, K., Amin, B. D., Sari, S. S., \& Hakim, A. (2021). The development of higher order-thinking skills (HOTS) instrument assessment in physics study. Journal of Physics: Conference Series, 1899(1), 012140. https://doi.org/10.1088/1742-6596/1899/1/012140

Binali, T., Tsai, C.-C., \& Chang, H.-Y. (2021). University students' profiles of online learning and their relation to online metacognitive regulation and internet-specific epistemic justification. Computers \& Education, 175, 104315. https://doi.org/10.1016/j.compedu.2021.104315

Dermawan, D. A., Siagian, P., \& Sinaga, B. (2021). Analysis of students' mathematical problem solving 
ability in terms of student learning styles with models problem based learning. Budapest International Research and Critics in Linguistics and Education (BirLE) Journal, 4(1), 337-344. https://doi.org/10.33258/birle.v4i1.1607

Falloon, G. (2019). Using simulations to teach young students science concepts: An Experiential Learning theoretical analysis. Computers \& Education, 135, 138-159. https://doi.org/10.1016/j.compedu.2019.03.001

Gamboa Mora, M. C., Vera-Monroy, S. P., Mejía-Camacho, A., \& Guerrero Rueda, W. J. (2021). Perception channels and cognitive styles: opponents, followers or learning allies? Heliyon, 7(2), e06242. https://doi.org/10.1016/j.heliyon.2021.e06242

Hajaro, U., Nayazik, A., \& Kusumawati, R. (2021). Analysis of david kolb's learning style according to mathematical representation ability. Journal of Medives : Journal of Mathematics Education IKIP Veteran Semarang, 5(2), 403. https://doi.org/10.31331/medivesveteran.v5i2.1709

Istiningtiyas, D. (2021). The influence of learning style on achievement through motivation as a moderator variable. Jurnal Pendidikan Bahasa Inggris Proficiency, 3(2), 20. https://doi.org/10.32503/proficiency.v3i2.1917

Jalinus, N., Ganefri, G., Syahril, S., Wulansari, R. E., Nabawi, R. A., Yunos, J. M., \& Kiong, T. T. (2020). Comparison of learning style between engineering and non-engineering students in vocational education. International Journal of Innovation, Creativity and Change, 13(12), 283-294. https://www.ijicc.net/images/vol_13/Iss_12/131226_Jalinus_2020_E_R.pdf

Jarvis, M. A., \& Baloyi, O. B. (2020). Scaffolding in reflective journaling: A means to develop higher order thinking skills in undergraduate learners. International Journal of Africa Nursing Sciences, 12, 100195. https://doi.org/10.1016/j.ijans.2020.100195

Kholid, M. N., Hamida, P. S., Pradana, L. N., \& Maharani, S. (2020). Students' critical thinking depends on their cognitive style. International Journal of Scientific and Technology Research, 9(1), 1045-1049.

Kwangmuang, P., Jarutkamolpong, S., Sangboonraung, W., \& Daungtod, S. (2021). The development of learning innovation to enhance higher order thinking skills for students in Thailand junior high schools. Heliyon, 7(6), e07309. https://doi.org/10.1016/j.heliyon.2021.e07309

Lwande, C., Muchemi, L., \& Oboko, R. (2021). Identifying learning styles and cognitive traits in a learning management system. Heliyon, 7(8), e07701. https://doi.org/10.1016/j.heliyon.2021.e07701

McKenna, L., Copnell, B., Butler, A. E., \& Lau, R. (2018). Learning style preferences of Australian accelerated postgraduate pre-registration nursing students: A cross-sectional survey. Nurse Education in Practice, 28(October), 280-284. https://doi.org/10.1016/j.nepr.2017.10.011

Pantas, A. A., \& Hasruddin, H. (2020). The influence of student learning style on higher order thinking skill (HOTS) of cell structure and function topic. Jurnal Pelita Pendidikan, 8(1), 71-79. https://doi.org/10.24114/jpp.v8i1.11251

Patricia Aguilera-Hermida, A. (2020). College students' use and acceptance of emergency online learning due to COVID-19. International Journal of Educational Research Open, 1, 100011. https://doi.org/10.1016/j.ijedro.2020.100011

Retnawati, H., Djidu, H., Kartianom, A., \& Anazifa, R. D. (2018). Teachers' knowledge about higherorder thinking skills and its learning strategy. Problems of Education in the 21st Century, 76(2), 215. https://www.ceeol.com/search/article-detail id $=942236$

Sen, S., \& Yilmaz, A. (2012). The effect of learning styles on student's misconceptions and selfefficacy for learning and performance. Procedia - Social and Behavioral Sciences, 46, 1482-1486. https://doi.org/10.1016/j.sbspro.2012.05.325

Tyas, M. A., Nurkamto, J., Marmanto, S., \& Laksani, H. (2019). Developing higher order thinking skills (HOTS) - Based questions: Indonesian EFL teachers' challenges. Proceeding of the 2nd 
International Conference on Future of Education, 2(1), 52-63.

https://doi.org/10.17501/26307413.2019.2106

Vasil'ev, E. N., \& Gorelikov, A. I. (1998). Radiation pattern of the horn with the corrugated flange. Huagong Kuangshan Jishu/Technology for Chemical Mines, 27(4), 46-50.

Viloria, A., Gonzalez, I. R. P., \& Lezama, O. B. P. (2019). Learning style preferences of college students using big data. Procedia Computer Science, 160, 461-466.

https://doi.org/10.1016/j.procs.2019.11.064

Yuniarti, A. P., Pramudya, I., \& Slamet, I. (2021). Analysis of mathematical creative thinking skill in student with kinesthetic learning style. International Journal of Multicultural and Multireligious Understanding, 8(4), 128. https://doi.org/10.18415/ijmmu.v8i4.2451

Zhong, B., \& Wang, Y. (2021). Effects of roles assignment and learning styles on pair learning in robotics education. International Journal of Technology and Design Education, 31(1), 41-59. https://doi.org/10.1007/s10798-019-09536-2 